\title{
The Impact of Anxiety on Perceptions during the Lockdown of COVID-19
}

\author{
REJLA BOZDO \\ Department of Marketing and Tourism \\ University of Tirana, Faculty of Economy \\ Elbasani St, Tirana, 1005 \\ ALBANIA
}

\begin{abstract}
The world faced a new way of organizing everyday life in many countries during 2019. Lockdowns applied in many societies. People adopted a "new way" of living called "the new normal". The tense days spent under the virus threat made people experience changes in their daily lives, plus it forced them into behaving differently than before when the fear of any pandemic was almost nonexistent.

This research was conducted during the days of lockdown and it indicates the feelings people experienced during the conditions of lockdown, in particular: on the magnitude of anxiety they felt, how anxiety may have affected perceptions and behaviors related to economy; furthermore, on the perceptions of economic crisis. Also gender differences were tested regarding the above.

An online survey was conducted in Albania from March $22^{\text {nd }}$ to April $4^{\text {th }}, 2020$, during the lockdown period of COVID-19. Since the 9 of March 2020, the Albanian government started issuing the anti-COVID-19 measures

that were toughened later in the following weeks of March and April. The education institutions were closed and other public and private services were limited. The government issued a strict curfew allowing people to go out in limited hours, in some days up to one hour. Some weekends the curfew lasted for 24-48 hours in isolation where citizens were prohibited to walk outside of their homes. Transportation was limited to the employee shuttles and distribution transportation services only. Private cars were not allowed for many weeks. Physical stores were closed; only those selling food could open for limited hours.

1205 respondents participated in this online survey, from which 1061 valid questionnaires were analyzed, in a sample of $66.2 \%$ female and $33.8 \%$ male, providing data regarding their feelings during quarantine, their decisions related to future spending and how they perceived the future economic situation.

The aim is to investigate the relation between anxiety and economic crises perceptions, the levels of anxiety and decision-makings on future spending and if there is any variance affected by gender, in order to have an outcome on the assumption that anxiety feelings may affect peoples' behavior as consumers.

The results of this research show that there are differences between male and female groups on the levels of anxiety experienced during the lockdown and on the level of perception of future economic crisis, but there is no difference between gender groups regarding the decision in reducing future spending. Another finding from this research is that people experiencing high levels of anxiety, were more likely to lessen their future expenses. Also, there is a significant relationship between anxiety and the level of perception on the fear of future economic crisis in the country. People with high levels of anxiety, perceive a higher level of crisis. There is a significant relationship between anxiety and decision-making of reducing the future spending. People with high levels of anxiety, have higher levels of reduction of future spending. The decreasing of future spending is related more to the perception of future economic crisis than to feelings of anxiety.
\end{abstract}

Key-Words: - COVID-19, anxiety, perception on economy, gender differences, lockdown

Received: October 14, 2020. Revised: February 1, 2021. Accepted: February 19, 2021. Published: March 3, 2021.

\section{Introduction}

During 2019-2020, the world experienced the pandemic of COVID-19. Many countries around the world enforced lockdowns to decelerate the spread of Covid-19.
Covid-19 crisis exposed the whole world to new challenges in changing consumer behavior due to social distancing and the lockdown measures adopted by retailers, manufacturers and governments. While changing their lifestyle, people were worried about their health and the health of their families. Several 
researches, conducted during the time of lockdowns in many countries, show that consumers were deeply concerned about the impact of COVID-19, both from a health and economic perspective. Some consumers felt anxious and worried, while in contrast, others remained indifferent to the pandemic and continued their business activity as usual.

As consumer behavior changed every week during the coronavirus, GfK classified these behaviors in three phases: the panic phase, the adapt phase and the new normal [1].

By changing the consumer behavior due to lockdown measures and the social distancing, consumers change their feelings towards life in general and the economy. The way consumers perceive the situations affect their actual and future spending, consumption and investments.

A research conducted by McKinsey reports that consumer optimism has fallen across the Americas and Europe since mid-March, but the research also showed a difference between cultures regarding consumer optimism levels [2]. It also states that during this period the consumers' expectations on future incomes were negative. Consumers expected lower incomes in the upcoming weeks [2].

According to the survey of EY, that shows how people changed their behavior during lockdown, 4,859 consumers were surveyed across the US, Canada, UK, France and Germany during the week of 6 April 2020 on current behaviors, sentiment and intent and there were identified four segments of behavior: Save and Stockpile (35\%), Cut Deep (27\%), Stay Calm, Carry On (26\%), Hibernate and Spend (11\%) [3]. This means that there was a clear trend throughout the countries on lockdown restrictions to decrease expenses.

During the lockdown restrictions people were exposed to a new way of living. They started working online, more meals were consumed at home, entertainment also happened at home, people were not allowed to go outside or they were allowed but in limited hours. Changing the daily routine and being submissive to restrictions had a psychological impact to people, which includes the emotional state of anxiety.

Professor Simon Wessely, of King's College London, stated that the pandemic "creates intense anxiety, but the measures that we need to control the pandemic, which center on suppressing our ability to interact socially, make it more difficult to manage that anxiety” [4].
Nuffield Health reported a research that supports the idea that the situation created by the pandemic along with the measures taken to slow down the spread of the virus, is impacting the mental health by stating that "around $80 \%$ of British people working from home feel lockdown has had a negative impact on their mental health, while $25 \%$ said they were finding it difficult to cope with the emotional challenges of isolation" [5].

The survey of Office of National Statistics, conducted from the $9^{\text {th }}$ to $13^{\text {th }}$ of September 2020, in regards to the question "In the past seven days, how has your well-being being affected?” shows that $65 \%$ of the surveyed sample is feeling stressed and anxious and $61 \%$ of it is feeling worried about the future [6].

In their research the authors Durante and Laran have stated that there is a relation between stress and how people spend their money. "Stress leads consumers to save money in general, but spend strategically on products that are perceived to be necessities” [7]. This means that, during decision-buying processes, consumer behavior changes in times of stress by being oriented towards products that are necessary in everyday life, thus people tend to increase their savings in these times of uncertainties.

\section{Methodology}

An online survey was conducted in Albania among 1205 respondents, during 22 March 2020 to $4^{\text {th }}$ April 2020.

\subsection{Research Context}

Since the $9^{\text {th }}$ of March 2020, the Albanian government started issuing the anti-COVID-19 measures that were toughened in the following weeks of March and April. The education institutions were closed and other public and private services were limited. The government issued a strict curfew allowing people to go out in limited hours, in some days up to one hour. On some weekends the curfew lasted for 24-48 hours in isolation where citizens were prohibited to walk outside of their homes. Transportation was limited to the employee shuttles and distribution transportation services only. Private cars were not allowed for many weeks. Physical stores were closed; only those selling food could open in limited hours. Albania is one of the countries that had firm measures against COVID-19. 


\subsection{Participants}

The survey, conducted among 1205 respondents, of which 1061 questionnaires were considered as valid, a sample composed by $66.2 \%$ females and $33.8 \%$ males, investigated how people were reacting to the lockdown experience, how their behavior was influenced by the restrictions, the news and the situation in general, causing any emotional state of anxiety and how they perceive the future of economy. Average age of participants is 31.84 years old.

\subsection{Research Questions}

This paper aims to give answers to the following research questions:

1. Are there differences between genders (male and female) regarding the variable anxiety?

2. Is there any difference between genders in perceiving the future economic crisis?

3. Is there any difference between genders in the decision of future spending?

4. What is the relation between anxiety and the perception of future economic crisis?

5. What is the relation between anxiety and the decision on future spending?

6. What is the relation between future economic crisis and decision on future spending?

\subsection{Instruments}

In this online survey, people were asked:

- to rate their level of anxiety in a scale from 0 to 10 where 0 is not at all and 10 is absolutely too much (Question: How much anxious do you feel?).

- to rate their level of their perception on future economic crisis in a scale from 0 to 10 where 0 is not at all and 10 is absolutely too much (Question: Do you think that there will be a deep economic crisis in Albania?).

- $\quad$ to rate the level of reducing their future spending in a scale from 0 to 10 where 0 is not at all and 10 is absolutely too much (Question: How much are you going to reduce future spending?).

\subsection{Data Analysis}

The data was analyzed through SPSS 22.0 using descriptive statistics, correlation, independent t-test and linear regression. Descriptive statistics give a clear picture of the behavior in general; statistical tests explain the relations between variables of anxiety, behavior, perception and the differences between genders.

\subsection{Research Limitations}

The results of this study are limited to the context of the research. The survey was conducted during the first weeks of lockdown when the uncertainty was at very high levels and the information on the virus and how it should be treated was at very low levels. This context is a lot different compared to other weeks when lockdowns occurred but that situation wasn't new anymore to people. The average age of participant in the study, 31.84 years old can be another limitation of this research.

\section{Research Results and Findings}

1061 questionaries of this survey were considered as valid, form which $66.2 \%$ males and 33.8 females. (Table 1).

Table 1. Gender frequency and percentage.

\begin{tabular}{|r|r|r|r|r|}
\multicolumn{6}{|c}{ Gender } \\
\hline & Frequency & Percent & $\begin{array}{c}\text { Valid } \\
\text { Percent }\end{array}$ & $\begin{array}{c}\text { Cumulative } \\
\text { Percent }\end{array}$ \\
\hline Valid Male & 359 & 33.8 & 33.8 & 33.8 \\
Female & 702 & 66.2 & 66.2 & 100.0 \\
Total & 1061 & 100.0 & 100.0 & \\
\hline
\end{tabular}

There are three variables taken in consideration in this study.

Anxiety - represents the level of anxiety of the respondents

Crisis - represents the level of perception on future economic crisis in the country of the respondents Spending - represents the level of reduction of future spending by the respondents

The differences in the means of the groups (male and female) for the variable Anxiety is 1.23, showing that females feel, on average, more anxious than males. The differences in the means of the groups of males and females for the variable Perception of Future Crises is 0.47. Thus, showing that females perceive 
potential future economic crises at a higher level compared to males, implying that female are more concerned about future crisis in economy even though the difference is less than 1 at the scale from 0 to 10 . The differences in the means of the groups of males and females for the variable Reduction of Future Spending is 0.09. (Table 2).

Table 2. Descriptive statistics for variables regarding male and female groups.

\section{Group Statistics}

\begin{tabular}{|ll|r|r|r|r|}
\hline \multicolumn{2}{|c|}{ Gender } & $\mathrm{N}$ & Mean & $\begin{array}{c}\text { Std. } \\
\text { Deviation }\end{array}$ & $\begin{array}{c}\text { Std. } \\
\text { Error } \\
\text { Mean }\end{array}$ \\
\hline Level of anxiety & Male & 359 & 5.19 & 2.904 & .153 \\
\cline { 2 - 6 } & Female & 702 & 6.42 & 2.598 & .098 \\
\hline $\begin{array}{l}\text { Perception of } \\
\text { future economic } \\
\text { crises }\end{array}$ & Male & 359 & 5.60 & 2.842 & .150 \\
\cline { 2 - 6 } $\begin{array}{l}\text { Level of } \\
\text { reduction in } \\
\text { future spending }\end{array}$ & Female & 702 & 6.07 & 2.669 & .101 \\
\cline { 2 - 6 } & Female & 359 & 8.33 & 2.228 & .118 \\
\cline { 5 - 6 } & 702 & 8.42 & 1.896 & .072 \\
\hline
\end{tabular}

Distribution of data for each variable illustrates that the percentages rating zero value (as the minimum level) and 10 (as the maximum level), are as below:

Table 3. Minimal and maximal distribution in each variable.

\begin{tabular}{|l|c|c|}
\hline Variable & $\mathbf{0}$ & $\mathbf{1 0}$ \\
\hline Anxiety & $4.4 \%$ & $13.2 \%$ \\
\hline Crisis & $5.9 \%$ & $13.0 \%$ \\
\hline Spending & $0.6 \%$ & $45.8 \%$ \\
\hline
\end{tabular}

Using Independent T-test, was analyzed if there is difference between groups (males and females) for the three variables: Anxiety, Perception of Future Crises, and Reduction of Future Spending.

The t-test indicates that there are group differences for the Anxiety variable suggesting that the male and female levels of experiencing anxiety during the quarantine are affected by gender. Their means in descriptive statistics are: males 5.19 and females 6.42 in a scale from 0 to 10 where 0 is not at all and 10 is absolutely too much. The $\mathrm{p}<0.01$ tells us that there is significant difference between groups for the variable of Anxiety. ( $\mathrm{p}=.000)$.

Pearson Coefficient for the correlation of the variables Gender/Anxiety shows that there is a positive relation between variables, but this relation is week. $(r=0.210)$. (Table 4)

Table 4. Correlations of Gender and Anxiety levels.

\begin{tabular}{|c|c|c|c|}
\hline \multicolumn{4}{|c|}{ Correlations } \\
\hline & & Gender & $\begin{array}{c}\text { Level of } \\
\text { anxiety }\end{array}$ \\
\hline \multirow[t]{3}{*}{ Gender } & $\begin{array}{l}\text { Pearson } \\
\text { Correlation }\end{array}$ & 1 & $.210^{* *}$ \\
\hline & Sig. (2-tailed) & & .000 \\
\hline & $\mathrm{N}$ & 1061 & 1061 \\
\hline \multirow[t]{3}{*}{$\begin{array}{l}\text { Level of } \\
\text { anxiety }\end{array}$} & $\begin{array}{l}\text { Pearson } \\
\text { Correlation }\end{array}$ & $.210^{* *}$ & \\
\hline & Sig. (2-tailed) & .000 & \\
\hline & $\mathrm{N}$ & 1061 & 1061 \\
\hline
\end{tabular}

The t-test also shows that there are group differences for the variable of Crisis, indicating that male and female levels of perceiving crises during the quarantine are affected by gender. Their means in descriptive statistics are: males 5.06 and females 6.07 in a scale from 0 to 10 where 0 is not at all and 10 is absolutely too much. The $\mathrm{p}<0.01$ identifies that there is significant difference between groups for the variable of Crisis. ( $\mathrm{p}=.009)$ (Table 4)

Pearson Coefficient for the correlation of the variables Gender/Crisis perception explains that there is a positive relation between variables, but this relation is very week. $(\mathrm{r}=0.081)$. (Table 5$)$ 
Table 5. Correlations of Gender and Perception of future economic Crisis.

\section{Correlations}

\begin{tabular}{|ll|r|r|}
\hline & Gender & $\begin{array}{c}\text { Perception } \\
\text { of future } \\
\text { economic } \\
\text { crises }\end{array}$ \\
\hline Gender & $\begin{array}{r}\text { Pearson } \\
\text { Correlation } \\
\text { Sig. (2-tailed) } \\
\mathrm{N}\end{array}$ & 1 & $.081^{* *}$ \\
\hline Perception of future Pearson & 1061 & 1009 \\
economic crises & $\begin{array}{l}\text { Correlation } \\
\text { Sig. (2-tailed) } \\
\mathrm{N}\end{array}$ & $.081^{* *}$ & 1 \\
& .009 & \\
\hline
\end{tabular}

**Correlation is significant at the 0.01 level (2-tailed).

The t-test shows that there are no group differences for the variable Reduction in Spending, indicating that male and female decision-making during the quarantine on reducing the future spending is not affected by gender. (Table 4) Their means in descriptive statistics are: males 8.33 and females 8.42 in a scale from 0 to 10 where 0 is not at all and 10 is absolutely too much. The $\mathrm{p}>0.01$ identifies that there is not any significant difference between groups for the variable of Reduction in Spending. ( $\mathrm{p}=.500)$. The correlation analysis for these two variables results of not being significant. (Table 6).

Table 6. Correlations of Gender and Perception of future economic Crisis.

\section{Correlations}

\begin{tabular}{|c|r|r|}
\hline & Gender & $\begin{array}{c}\text { Level of } \\
\text { reduction } \\
\text { in future } \\
\text { spending }\end{array}$ \\
\hline Gender & 1 & .022 \\
Cearson & & .477 \\
Sig. (2-tailed) & 1061 & 1061 \\
$\mathrm{~N}$ & .022 & 1 \\
\hline Level of reductionPearson & .477 & \\
in future spending Correlation & 1061 & 1061 \\
\hline Sig. (2-tailed) & $\mathrm{N}$ &
\end{tabular}

Below, it is analyzed the relation between variables of: Anxiety and Crises, Anxiety and Reduction of Spending and Crises and Reduction of Spending. The findings are related to the level of the variability for each pair of variables.

Table 7. Model Anxiety/Future spending.

\section{Model Summary}

\begin{tabular}{|c|c|c|c|c|c|c|c|c|c|}
\hline \multirow[b]{2}{*}{$\begin{array}{l}\mathrm{M} \\
\mathrm{od} \\
\mathrm{el}\end{array}$} & \multirow[b]{2}{*}{$\mathrm{R}$} & \multirow[b]{2}{*}{\begin{tabular}{|c|}
$\mathrm{R}$ \\
Squa \\
re \\
\end{tabular}} & \multirow[b]{2}{*}{$\begin{array}{c}\text { Adjust } \\
\text { ed R } \\
\text { Square }\end{array}$} & \multirow{2}{*}{$\begin{array}{c}\text { Std. } \\
\text { Error } \\
\text { of the } \\
\text { Estima } \\
\text { te } \\
\end{array}$} & \multicolumn{5}{|c|}{ Change Statistics } \\
\hline & & & & & $\begin{array}{c}\text { R } \\
\text { Square } \\
\text { Chang } \\
\text { e }\end{array}$ & $\begin{array}{c}\text { F } \\
\text { Chan } \\
\text { ge }\end{array}$ & df1 & df2 & $\begin{array}{l}\text { Sig. F } \\
\text { Chang } \\
\text { e }\end{array}$ \\
\hline 1 & $\begin{array}{r}.16 \\
0^{\mathrm{a}}\end{array}$ & 026 & .025 & 1.989 & .026 & $\begin{array}{r}27.7 \\
27\end{array}$ & & 105 & .000 \\
\hline
\end{tabular}

a. Predictors: (Constant), Level of anxiety

$\mathrm{R}$ Square of .026 shows that only $2.6 \%$ of the decision to reduce future spending is affected by anxiety. (Table 7) This means that there are other factors that influence this decision; consequently, the interpretation addresses that most probably this decision is more rational than emotional.

Table 8. Model Anxiety/Perception on future economic Crisis

\section{Model Summary}

\begin{tabular}{|c|c|c|c|c|c|c|c|c|c|}
\hline \multirow[b]{2}{*}{$\begin{array}{l}\text { Mo } \\
\text { del }\end{array}$} & \multirow[b]{2}{*}{$\mathrm{R}$} & \multirow[b]{2}{*}{\begin{tabular}{|c}
$\mathrm{R}$ \\
Squ \\
are
\end{tabular}} & \multirow[b]{2}{*}{$\begin{array}{c}\text { Adjus } \\
\text { ted R } \\
\text { Squar } \\
\text { e }\end{array}$} & \multirow[b]{2}{*}{\begin{tabular}{|} 
Std. \\
Error \\
of the \\
Estim \\
ate
\end{tabular}} & \multicolumn{5}{|c|}{ Change Statistics } \\
\hline & & & & & $\begin{array}{c}\mathrm{R} \\
\text { Squar } \\
\mathrm{e} \\
\text { Chang } \\
\mathrm{e}\end{array}$ & $\begin{array}{c}\text { F } \\
\text { Cha } \\
\text { nge }\end{array}$ & df1 & df2 & $\mid \begin{array}{c}\text { Sig. F } \\
\text { Chang } \\
\text { e }\end{array}$ \\
\hline 1 & $\begin{array}{r}.19 \\
7^{\mathrm{a}} \\
\end{array}$ & .039 & .038 & 2.684 & .039 & $\begin{array}{r}42.8 \\
72\end{array}$ & & $\begin{array}{r}105 \\
9\end{array}$ & .000 \\
\hline
\end{tabular}

a. Predictors: (Constant), Level of anxiety

R Square of .039 shows that only $3.9 \%$ of the perception of future economic crises is affected by anxiety. (Table 8) This implies that there are other factors that influence this perception. In consideration of Albania, another variable to consider is the political situation, which has been instable lately.

The regression model of Future Economic Crises and Future Reduction of Spending is a relation where 
$10.8 \%$ of reduction is attributed to the perception of crises. (Table 9).

Table 9. Model Future Economic Crisis/Future Reduction of Spending.

\begin{tabular}{|c|c|c|c|c|c|c|c|c|c|}
\hline \multicolumn{10}{|c|}{ Model Summary } \\
\hline \multirow[b]{2}{*}{$\begin{array}{l}\mathrm{M} \\
\mathrm{od} \\
\mathrm{el}\end{array}$} & \multirow[b]{2}{*}{$\mathrm{R}$} & \multirow[b]{2}{*}{$\begin{array}{c}\mathrm{R} \\
\text { Squ } \\
\text { are }\end{array}$} & \multirow[b]{2}{*}{$\mid \begin{array}{c}\text { Adjus } \\
\text { ted R } \\
\text { Squar } \\
\text { e }\end{array}$} & \multirow[b]{2}{*}{\begin{tabular}{|c} 
Std. \\
Error \\
of the \\
Estim \\
ate
\end{tabular}} & \multicolumn{5}{|c|}{ Change Statistics } \\
\hline & & & & & $\begin{array}{c}\text { R } \\
\text { Squar } \\
\text { e } \\
\text { Chan } \\
\text { ge }\end{array}$ & $\begin{array}{c}\text { F } \\
\text { Cha } \\
\text { nge }\end{array}$ & df1 & df2 & $\begin{array}{c}\text { Sig. F } \\
\text { Chan } \\
\text { ge }\end{array}$ \\
\hline 1 & $\begin{array}{r}.32 \\
8^{\mathrm{a}}\end{array}$ & .108 & .107 & 1.903 & .108 & $\mid \begin{array}{l}127 . \\
727\end{array}$ & & $\left.1\right|_{9} ^{105}$ & 9.000 \\
\hline
\end{tabular}

a. Predictors: (Constant), Perception of future economic crises

\section{Conclusions}

The sample of data gathered through online survey in Albania during the lockdown, from the $22^{\text {nd }}$ of March to the $4^{\text {th }}$ of April 2020, demonstrates that: - anxiety levels were on average 5.19 for males and 6.42 for females in a scale of $0-10$ and there is significant difference between groups. Pearson Coefficient for the correlation of the variables Gender/Anxiety shows that there was a positive relation between variables, but this relation was week. $(\mathrm{r}=0.210)$.

- perception of future crises were on average 5.60 for males and 6.97 for females in a scale of $0-10$ and there is significant difference between groups. Pearson Coefficient for the correlation of the variables Gender/Crisis perception proves that there was a positive relation between variables, but this relation was very week. $(\mathrm{r}=0.081)$.

- level of reduction in future spending is on average 8.33 for males and 8.42 for females in a scale of $0-10$ and there was no significant variance between groups. Correlation analysis for these two variables results of not being significant.

There is a low distinction for the variables of Anxiety and Crises with $\mathrm{R}$ Squared of 0.026 showing that only $2.6 \%$ of people perception on future crisis is explained by their emotional state of anxiety.

There is a low distinction for the variables of Anxiety and Reduction of Spending with R Squared of 0.036 showing that only $3.6 \%$ of reduction in spending is explained by the emotional state of anxiety.

The variation for the variables Perception for Future Economic Crisis and Reduction of Spending with $\mathrm{R}$ Squared of 0.108 shows that $10.8 \%$ of spending reduction is explained by perceptions of future economic crisis.

The study demonstrates that the perceptions and decision-making, respectively, regarding the future crisis and the spending affected by anxiety were at a low level, indicating that other factors influenced these perceptions and decisions, hence should be considered in future studies.

\section{References:}

[1] GfK, 2020. Retrieved from: https://www.gfk.com/blog/how-retailers-canadapt-to-changing-consumer-behavior

[2] McKinsey, 2020, "Consumer sentiment is evolving as countries around the world begin to reopen'. Retrieved from: https://www.mckinsey.com/businessfunctions/marketing-and-sales/our-insights/aglobal-view-of-how-consumer-behavior-ischanging-amid-covid-19.

[3] EY, 2020, "Future Consumer Index: How COVID-19 is changing consumer behaviors". Retrieved from: https://www.ey.com/en_gl/consumer-productsretail/how-covid-19-could-change-consumerbehavior

[4] The Guardian (2020). Retrieved online on 21st September 2020, https://www.theguardian.com/global/2020/jun/2 1/im-broken-how-anxiety-and-stress-hitmillions-in-uk-covid-19-lockdown

[5] Nuffield Health (2020). Retrieved online on 21st September 2020 https://www.nuffieldhealth.com/article/workingfrom-home-taking-its-toll-on-the-mental-healthrelationships-of-the-nation

[6] Office of National Statistics, (2020). Retrieved online on 21st September 2020 https://www.ons.gov.uk/peoplepopulationandco mmunity/healthandsocialcare/healthandwellbeig /datasets/coronavirusandthesocialimpactsongreat britaindata 
[7] Durante, Laran (2016), The Effect of Stress on Consumer Saving and Spending, Journal of Marketing Research, AMA.

\section{Creative Commons Attribution License 4.0} (Attribution 4.0 International, CC BY 4.0)

This article is published under the terms of the Creative Commons Attribution License 4.0

https://creativecommons.org/licenses/by/4.0/deed.en_US 